\title{
Thoracic Spinal Epidural Angiolipoma: Report of Two Cases and Review of the Literature
}

\author{
Torasik Spinal Epidural Anjiyolipom: İki Olgu Sunumu ve Literatürün \\ Incelenmesi
}

\author{
Hiroyasu FUJIWARA ${ }^{1}$, Takashi KAITO ${ }^{1}$, Shota TAKENAKA², Takahiro MAKINO ${ }^{1}$, Kazuo YONENOBU ${ }^{1}$ \\ ${ }^{1}$ National Hospital Organization, Osaka Minami Medical Center, Department of Orthopaedic Surgery, Karwachinagano, Osaka, Japan \\ 2Osaka Kosei-Nenkin Hospital, Department of Orthopaedic Surgery, Fukushima, Osaka, Japan
}

Correspondence address: Hiroyasu FUJIWARA / E-mail: mld03108@nifty.com

\begin{abstract}
AIM: Spinal angiolipoma is a benign uncommon neoplasm composed of mature lipocytes admixed with abnormal blood vessels, and accounts for only $0.14-1.2 \%$ of all spinal tumors.

MATERIAL and METHODS: Retrospective data analysis.

RESULTS: We report two cases of a 64-year-old woman and a 65-year-old man with thoracic myelopathy due to spinal angiolipoma. Magnetic resonance imaging showed isointensity on T1-weighted imaging and hyperintensity on T2-weighted imaging and enhance with gadolinium administration. In one case, angiography elucidated the vascularity of the tumor and the relationship with concomitant hemangioma. Laminoplasty was performed to achieve tumor resection, and the postoperative course was uneventful with neurological improvement. Histopathological examination of the resected tumors revealed angiolipomas.

CONCLUSION: Although extremely rare, thoracic spinal epidural angiolipoma should be considered in the differential diagnosis of thoracic spinal lesions. Prognosis after surgical management of this lesion is favorable. Angiography was useful for preoperative evaluation of vascularity and the relationship with concomitant tumors.
\end{abstract}

KEYWORDS: Spinal epidural tumors, Angiolipoma, Myelopathy, Angiography

öz

AMAÇ: Spinal anjiyolipom nadir bir benign neoplazm olup anormal kan damarlarıyla karışmış matür lipositlerden oluşmuştur ve tüm spinal tümörlerin sadece \%0,14 - 1,2'sini oluşturur.

YÖNTEM ve GEREÇLER: Retrospektif veri analizi

BULGULAR: Spinal anjiyolipom nedeniyle torasik myelopatisi olan 64 yaşında bir kadın ve 65 yaşında bir erkek şeklinde iki vaka bildiriyoruz. Manyetik rezonans görüntüleme T1 ağırlıklı görüntülemede izointensite ve T2 ağırlıklı görüntülemede hiperintensite gösterdi ve gadolinyum uygulamasıyla güçleniyordu. Bir vakada anjiyografi tümörün vaskülaritesini ve eş zamanlı hemanjiyomla ilişkisini gösterdi. Tümör rezeksiyonu için laminoplasti yapıldı ve postoperatif seyir nörolojik düzelmeyle birlikte olaysız geçti. Rezeksiyonu yapılmış tümörlerin histopatolojik incelemesi anjiyolipom gösterdi.

SONUÇ: Çok nadir olsa da torasik spinal epidural anjiyolipom torasik spinal lezyonların ayırıcı tanısında dikkate alınmalıdır. Bu lezyonun cerrahi tedavisinden sonra prognoz olumludur. Vaskülaritenin ve eş zamanlı tümörlerle ilişkinin değerlendirilmesi için anjiyografi faydalı olmuştur.

ANAHTAR SÖZCÜKLER: Spinal epidural tümörler, Anjiyolipom, Myelopati, Anjiyografi

\section{INTRODUCTION}

Angiolipomas are common benign lesions, almost always located subcutaneously. In contrast, spinal angiolipoma (SAL) is a specific but benign uncommon neoplasm composed of mature lipocytes admixed with abnormal blood vessels, accounting for approximately $0.14-1.2 \%$ of all spinal axis tumors and $2-3 \%$ of epidural spinal tumors $(5,7,22)$. We report the cases of two patients with angiolipoma who presented with myelopathy, and review the clinical presentation, radiological appearance, treatment, histological characteristics, and outcomes for each case.

\section{CASE REPORT}

\section{Case 1}

A 64-year-old woman presented with a 2-year history of intermittent dysesthesia arising in the left leg. The dysesthesia had gradually exacerbated and expanded to the lower trunk with increasing back pain. Before visiting our hospital, she had started to suffer from gait disturbance caused by spasticity. Past medical history revealed hypertension, but she was otherwise healthy. Body mass index $\left(24.9 \mathrm{~kg} / \mathrm{m}^{2}\right) \mathrm{had}$ been stable for the preceding 2 years. Physical examination showed hyperreflexia of bilateral lower extremities with 
negative on ankle clonus, straight leg raising test (SLRT) and femoral nerve stretching test (FNST). Pinprick sensation was mildly decreased (8/10) below the T6 dermatome level, and vibration sense was decreased in both feet. No muscular weakness was evident in the lower extremities. Bladderbowel disturbance was evident as pollakiuria. Preoperative Japanese Orthopaedic Association (JOA) score for thoracic myelopathy (maximum possible score, 11), derived from the JOA scoring system for cervical myelopathy by eliminating motor and sensory scores for the upper extremity (Table I) (13), was 6 (2-1-1-2).

Laboratory investigations and plain radiography revealed no abnormalities. Magnetic resonance imaging (MRI) before and after gadolinium administration identified a broad-based soft tissue mass of heterogeneous signal intensity along the posterior epidural spinal canal of the thoracic spine extending from T5 to T8. The spinal cord was compressed and displaced anteriorly (Figure $1 \mathrm{~A}-\mathrm{F}$ ). The mass was isointense on T1weighted imaging, hyperintense on T2-weighted imaging, and enhanced on contrast-enhanced T1-weighted imaging. Spinal angiography was undertaken to evaluate the feeding vessel for hemangioma at the adjacent vertebral body (T3) and the epidural tumor, and the origin of feeding vessels for these tumors. The feeding vessel for the epidural angiolipoma was independent from hemangioma and the vascularity was not particularly prominent (Figure $2 \mathrm{~A}, \mathrm{~B}$ ).

T5-T8 laminoplasty using a high-speed drill was performed to achieve tumor resection. The mass was excised from the dorsal dura mater without difficulty, and postoperative course was uneventful. The patient showed improved sensation in the days following surgery and was discharged in week 3 of hospitalization. Follow-up neurological examination at 3 years postoperatively showed just only hyperreflexia of bilateral lower extremities but no other abnormal findings. No tumor recurrence was evident on MRI. JOA score had recovered to 11 .

Macroscopically, the resected tumor demonstrated an elongated, encapsulated dark-red mass measuring $70 \mathrm{~mm}$ in length and $20 \mathrm{~mm}$ in width (Figure 3). Histological examination of the tumor showed mature adipose tissue interlaced with numerous blood vessels ranging from capillary to venular in

Table I: Japanese Orthopaedic Association Scoring System for Thoracic Myelopathy (JOA Score)

\begin{tabular}{|c|c|}
\hline Category & Score(Point) \\
\hline \multicolumn{2}{|l|}{ Motor function } \\
\hline \multicolumn{2}{|l|}{ Lower extremity } \\
\hline Unable to stand and walk by any means & 0 \\
\hline Unable to walk without a cane or other support on a level & 1 \\
\hline Walks independently on a level but needs support on stairs & 2 \\
\hline Capable of fast but clumsy walking & 3 \\
\hline Normal & 4 \\
\hline \multicolumn{2}{|l|}{ Sensory function } \\
\hline \multicolumn{2}{|l|}{ Lower extremity } \\
\hline Apparent sensory disturbance & 0 \\
\hline Minimal sensory disturbance & 1 \\
\hline Normal & 2 \\
\hline \multicolumn{2}{|l|}{ Trunk } \\
\hline Apparent sensory disturbance & 0 \\
\hline Minimal sensory disturbance & 1 \\
\hline Normal & 2 \\
\hline \multicolumn{2}{|l|}{ Bladder function } \\
\hline Urinary retension and/or incontinence & 0 \\
\hline Sense of retension and/or dribbling and/or thin stream and/or pollakiuria & 1 \\
\hline Urinary retardation and/or pollakiuria & 2 \\
\hline Normal & 3 \\
\hline
\end{tabular}


size, and a few are irregular in shape and have thickened walls (Figure $4 \mathrm{~A}, \mathrm{~B}$ ).

\section{Case 2}

A 65-year-old man presented with a 3-month history of dysesthesia spreading from the lower trunk to both lower extremities. Gait disturbance due to spasticity progressed during prostaglandin E1 treatment based on a misdiagnosis of lumbar canal stenosis, resulting in an inability to walk without walker. He had been healthy until the onset of dysesthesia, with no history of medical treatment. Body mass index (20.7 $\mathrm{kg} / \mathrm{m}^{2}$ ) had been stable for the preceding 3 months. Physical examination showed hyperreflexia of the lower extremities, clonus of both ankles, and negative on both SLRT and FNST. Pinprick sensation was severely decreased $(2 / 10)$ below the T7 dermatome level, and vibration sense was decreased in both feet. Muscular weakness was seen in the iliopsoas (4/4), quadriceps (3/3), tibialis anterior (4/4), and gastrocnemius $(1 / 1)$. He had also suffered from urinary retardation due to bladder-bowel disturbance. Preoperative JOA score was 5 (11-1-2) out of a possible 11.

Laboratory investigations and plain radiography revealed no abnormalities. MRI revealed a broad-based soft tissue mass of heterogeneous signal intensity along the posterior epidural spinal canal of the thoracic spine, extending from T5 to T7, and the spinal cord was compressed and displaced anteriorly (Figure 5 A-D). The mass was isointense on T1-weighted imaging and hyperintense on T2-weighted imaging.

T5-T7 laminoplasty using a high-speed drill was performed to achieve tumor resection. The mass was excised from the dorsal dura mater without difficulty and postoperative course
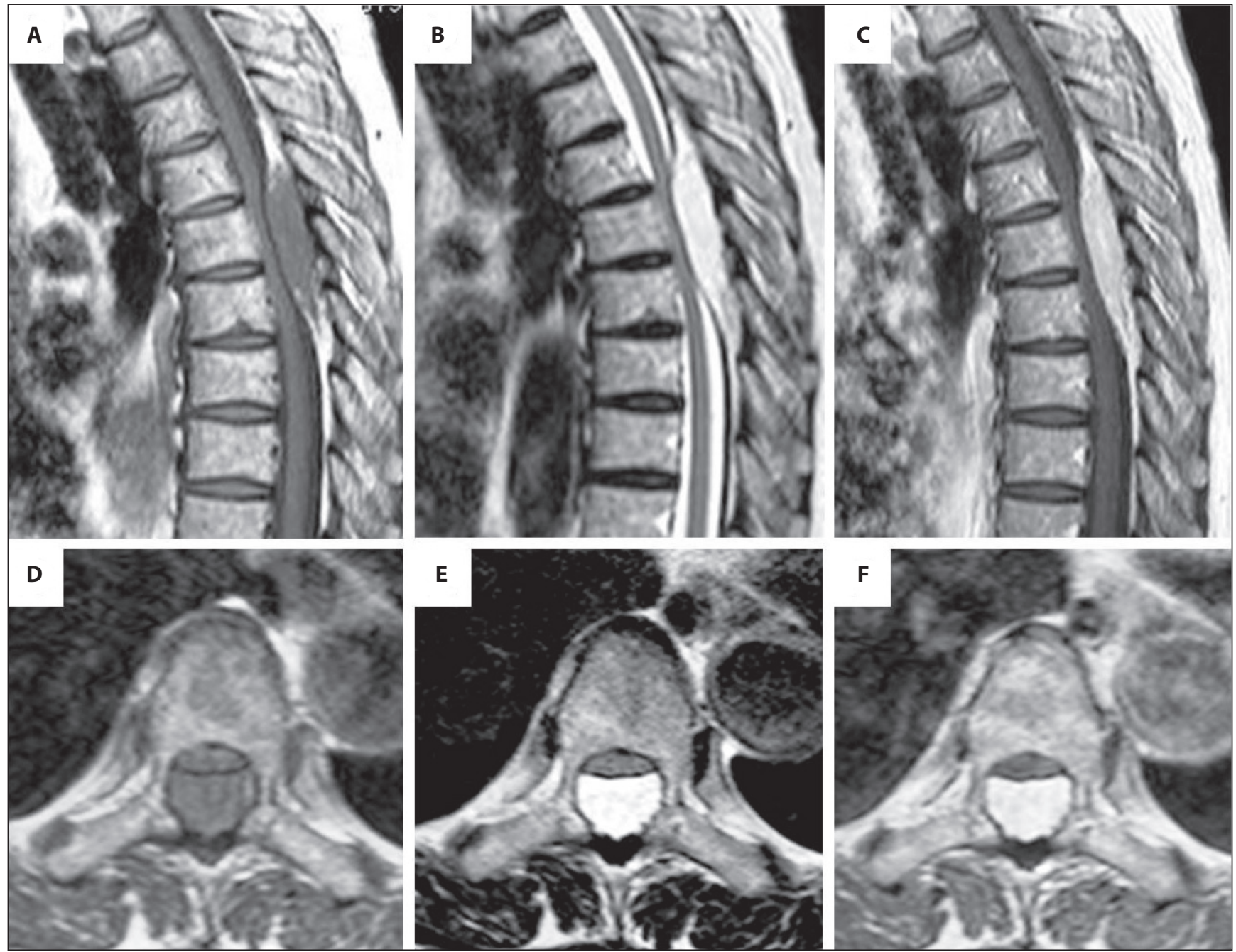

Figure 1: Case 1. A) Non-contrast T1-weighted sagittal MRI of the midthoracic spine showing a very inhomogenous mass, extending from T5 to T8. The tumor shows a large component hypointense to fat. B) T2-weighted sagittal MRI showing the mass as hyperintense relative to spinal cord and nearly isointense with normal fat. C) Post-contrast T1-weighted sagittal MRI showing diffuse, slightly inhomogenous enhancement of the mass. D-F) Non-contrast T1-weighted axial MRI (D), T2-weighted axial MRI (E), and post-contrast T1-weighted axial MRI (F) showing the mass along the posterior epidural spinal canal of the thoracic spine, compressing and displacing the spinal cord anteriorly. 


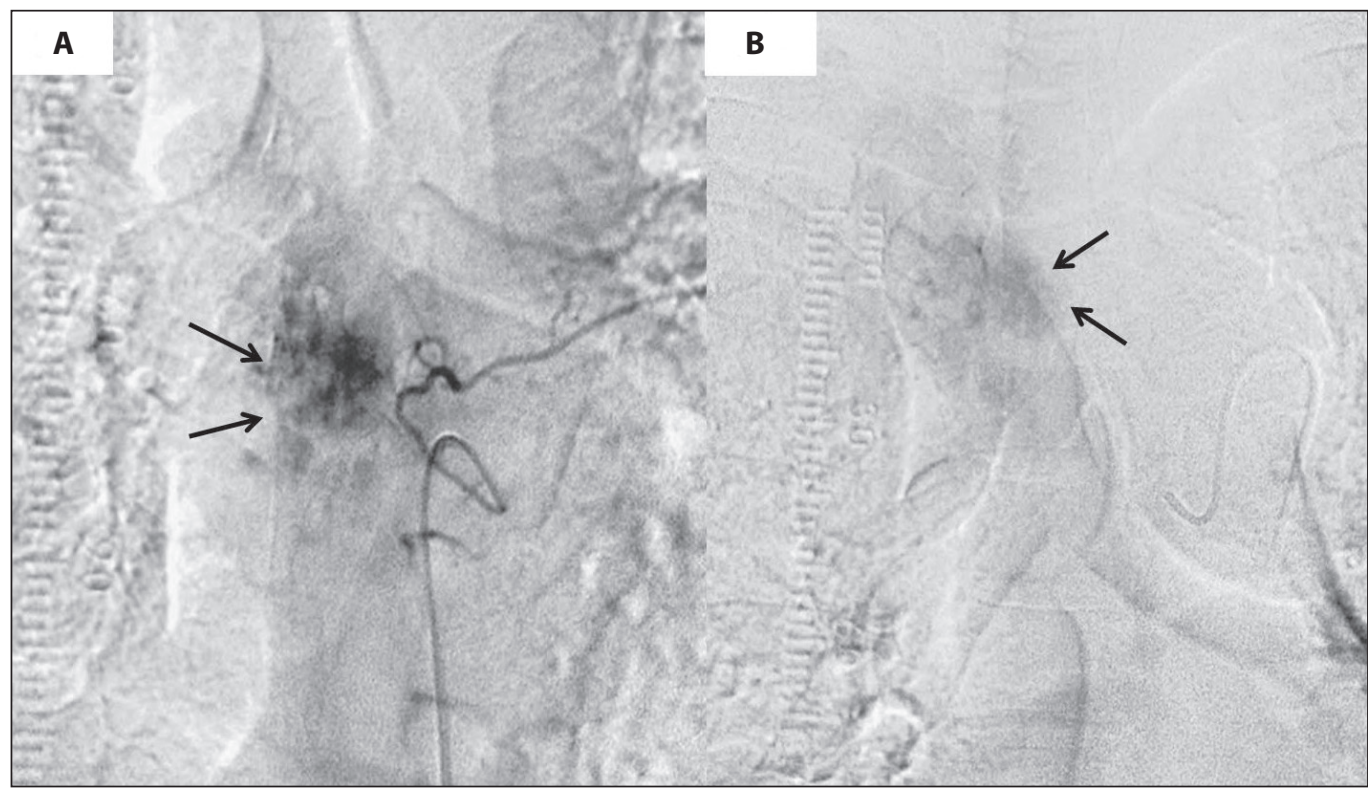

Figure 2: Case 1. A) The left sixth intercostal artery feeds the epidural tumor. B) The right bronchial artery feeds the hemangioma at the third thoracic vertebral body. No arteriovenous shunt or blood vessel malformation was evident.

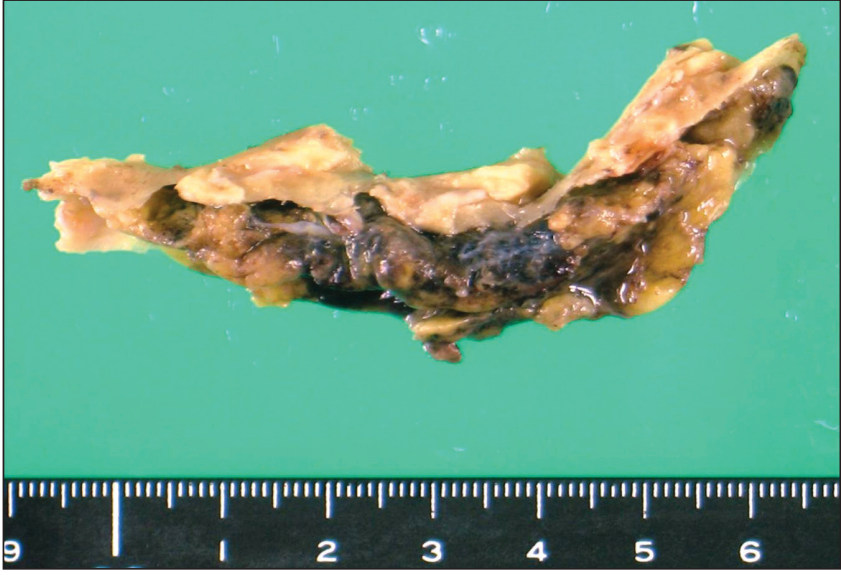

Figure 3: Case 1. The specimen demonstrated an elongated dark-red, encapsulated mass measuring $70 \mathrm{~mm}$ in length ' 20 $\mathrm{mm}$ in width.

was uneventful. The patient showed improved sensation in the days following surgery. Follow-up examination at 9 months postoperatively showed no abnormalities and no dysesthesia in either lower extremity, and no tumor recurrence was apparent on MRI. JOA score had recovered to 8 (3-1-13). Histological examination of the tumor showed lobules of mature adipocytes separated by thin-walled, cavernous vascular channels, and angiolipoma was diagnosed (Figure 6 $A, B)$.

\section{DISCUSSION}

SAL is a rare(11), but well-described, clinical pathological entity. SAL accounts for approximately $0.14-1.2 \%$ of all spinal axis tumors, and $2-3 \%$ of epidural spinal tumors $(5,7,22)$. The first published case of SAL was described by Berenbruch in 1890, about a 16-year-old boy with numerous cutaneous lipomas who developed progressive paraparesis with

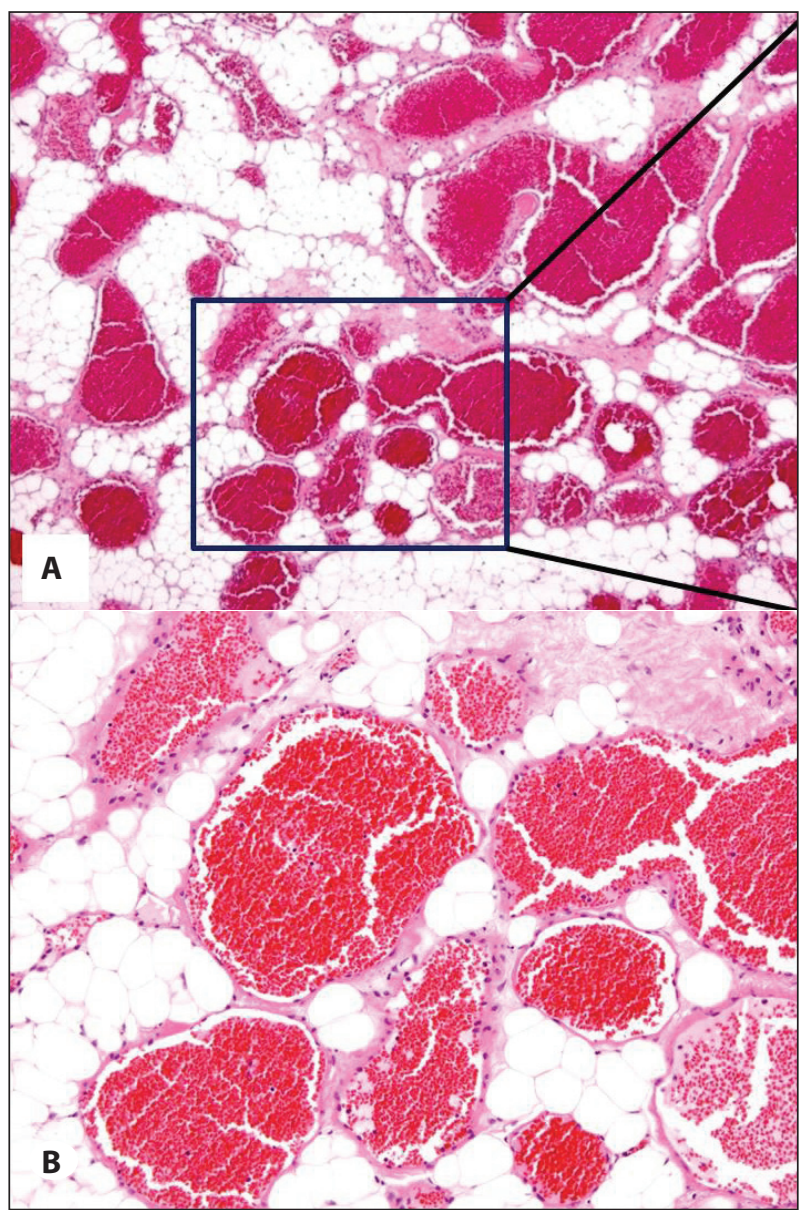

Figure 4: Case 1. Microscopically, the tumor showed mature adipose tissue interlaced with numerous blood vessels ranging from capillary to venular in size, and a few are irregular in shape and have tickened walls ranging from distended capillaries. Angiolipoma was diagnosed. Hematoxylin and eosin stain; magnification: A, '40; B, $\times 100$. 

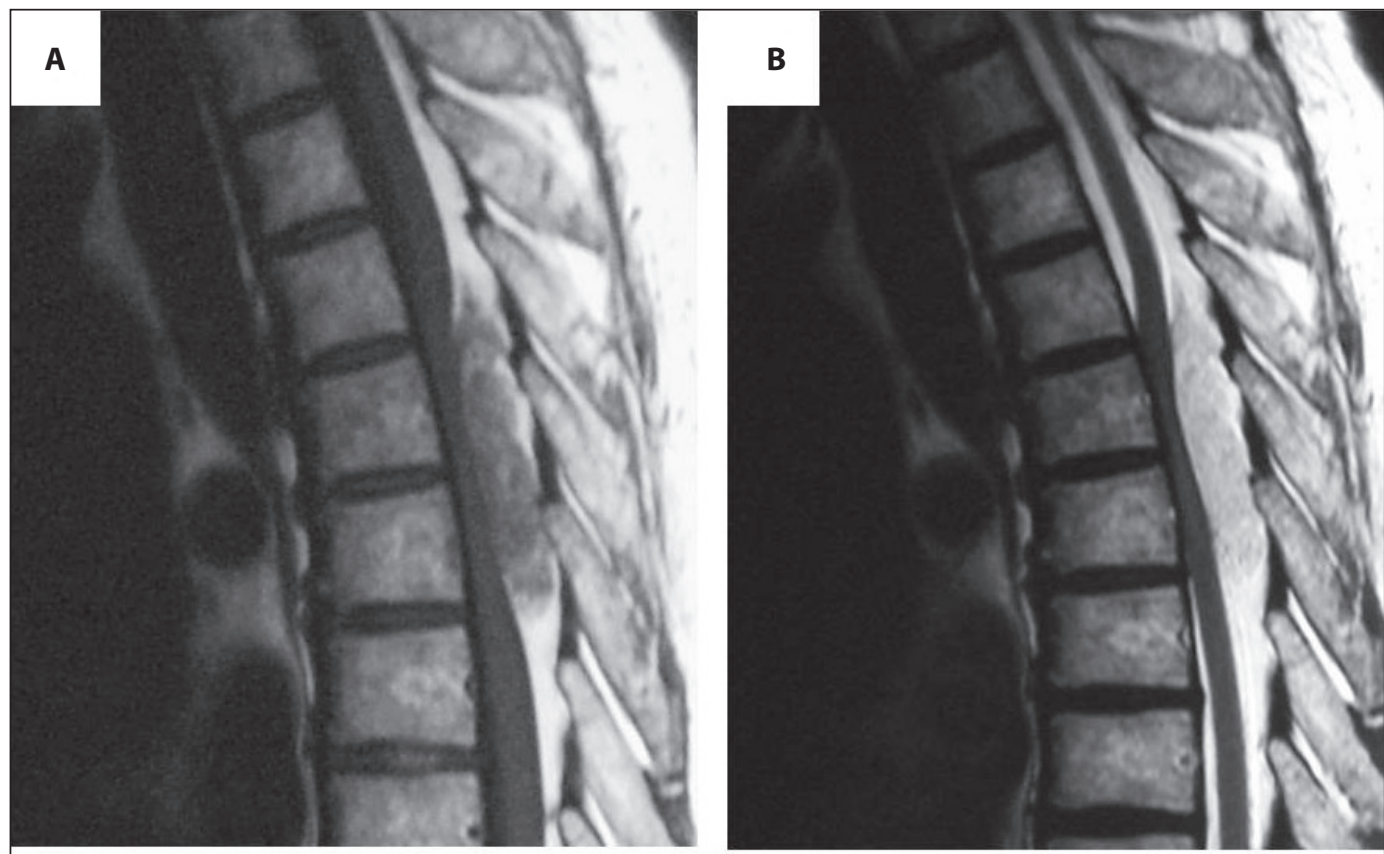

Figure 5: Case 2. A) Non-contrast T1weighted sagittal MRI of the mid-thoracic spine showing a very inhomogeneous mass, extending from $\mathrm{T} 5$ to $\mathrm{T} 7$, and with a large component hypointense
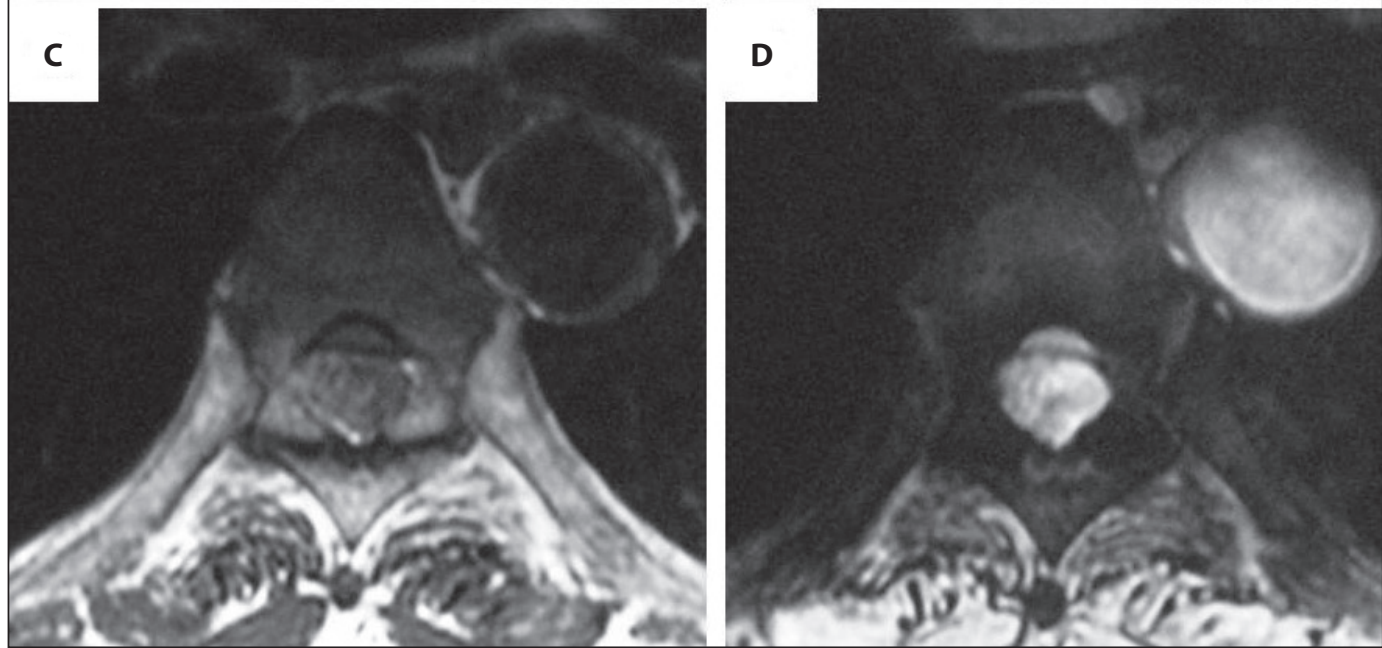
compared to fat. B) T2weighted sagittal MRI showing the mass as hyperintense relative to spinal cord and nearly isointense with normal fat. C, D) Non-contrast T1-weighted axial MRI (C) and T2-weighted axial MRI (D) showing the mass along the posterior epidural spinal canal of the thoracic spine. The spinal cord was compressed and displaced anteriorly.

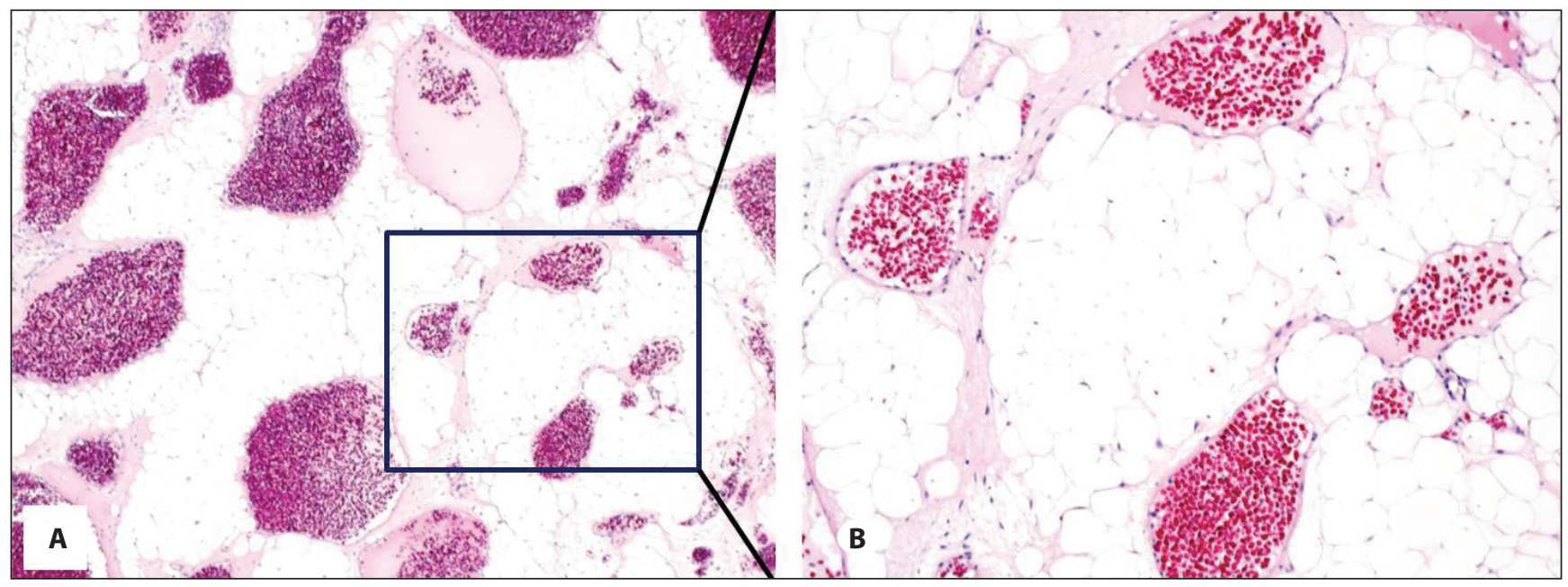

Figure 6: Case 2. Microscopically, the tumor was characterized by lobules of mature adipocytes separated by thin-walled, cavernous vascular channels. Hematoxylin and eosin stain; magnification: A, '40; B, ×100. 
hyperreflexia, and diagnosed at autopsy after unsuccessful surgical treatment(4). In 1974, Lin et al. classified angiolipomas into two subtypes. In the common type, angiolipoma is encapsulated and non-infiltrating, and shows a benign prognosis. The less common type is non-encapsulated and infiltrating, showing an unfavorable prognosis(12). Location of angiolipoma is informative for differentiating these two types. Almost all non-infiltrating epidural angiolipomas are located in the posterior or posterolateral space of the spinal canal (14). The infiltrating type is intramedullary (17) or intravertebral (12) occurrence. Intracranial occurrences are extremely rare $(23,25)$. SAL is more common among women, with a male:female ratio of 1:1.9 (6), and generally presents in the fourth or fifth decade of life. Few cases of pediatric SAL have been reported (8).

The clinical hallmark of SAL, though not specific, is the presence of symptoms related to spinal cord or nerve root compression. Neurological symptoms and signs vary according to tumor location and proliferation rate. Although SALs appear to be slow-growing, the anatomical location of these tumors predisposes them to produce early spinal cord compression due to the limited space available in the spinal canal. Symptoms usually progress over the course of months. The diagnosis is typically established in less than 1 year. Symptoms may fluctuate with pregnancy, body weight changes and other factors. Termination of pregnancy, as in the case reported by Preul et al. (19) can bring about regression of symptoms. The reasons for this fluctuation caused by pregnancy may be interference with spinal venous drainage and increased epidural venous pressure from compression of the pelvic and abdominal veins, hormonal changes, or increased adiposity (19). Other possible factors that can contribute to rapid deterioration include vascular steal phenomenon (24), pulsatile compressive effect on the adjacent cord (19) and tumor hemorrhaging (1). Obesity and steroid treatments can also exacerbate the symptom by increasing fatty component of the tumor (21). Our patients had remained within normal BMI, although the association of SAL with increased BMI has not been systematically studied. A relapsing clinical course can also mimic the clinical course of multiple sclerosis (2).

The variability of vascular and adipose elements in the tumor causes significant heterogeneity in imaging studies. Plain radiography often yields negative results, but might in some cases show erosions of the pedicle and widening of the spinal canal, and trabeculation of the affected vertebral body by infiltrating tumors $(18,20)$. Magnetic resonance imaging is considered the "gold standard" in diagnosing $\mathrm{SAL}$, which is typically isointense on T1-weighted imaging relative to other spinal tumors or epidural lipomatosis, and hyperintense on T2-weighted imaging. On T2-weighted imaging, SAL is only mildly hypointense relative to CSF and nearly isointense or slightly hypointense compared with epidural fat. Inhomogeneous enhancement is best seen on post-contrast T1-weighted imaging using fat-saturation techniques. The presence of large hypointense regions on T1- weighted imaging, correlating to a high vascular content, is predictive of the degree of vascularity to be encountered at surgery, although flow voids are not seen (20). Angiolipoma is reportedly detected by fluorodeoxyglucose (FDG)- positron emission tomography (PET) (9).

Histologically, SALs are composed of mature adipose tissue and blood vessels, features of which are described as being either normal or mimicking capillary angioma, cavernous angioma or arteriovenous malformations. The ratio of fat to vessels is variable, ranging from $1: 3$ to $2: 3$. Tumors with an abundance of smooth muscle proliferation are further subclassified as angiomyolipomas. A thin capsule surrounding the tumor, is often detectable in many cases (12).

Differential diagnoses include lipoma, hemangioma, malignant lymphoma, and nerve sheath tumor. Spinal angiography, which was performed in one of the present cases, is advantageous for differential diagnosis and evaluation of feeding vessels. The biological behaviors of infiltrating and non-infiltrating SAL imply the need for different treatment approaches. Similar to the approach in our case description, non-infiltrating SAL is often encapsulated, and complete removal of the tumor ensures no recurrence and allows improvement of neurological symptoms $(10,16)$. In cases of recurring or infiltrative SALs, wider resection followed by radiotherapy should be considered $(3,12,15)$.

\section{CONCLUSIONS}

In summary, SAL is a rare, but specific, clinicopathological entity composed of varying proportions of mature fat cells and abnormal vascular elements. Hallmarks are occurrence in middle-aged, predilection for female patients, localization in the dorsal epidural space of the thoracic spine, growth in a spindle shape along the spinal canal, a lack of associated malformations, and a benign course with good postoperative outcomes. Angiography is useful to evaluate vascularity of the tumor and relationship with concomitant tumors.

\section{REFERENCES}

1. Akhaddar A, Albouzidi A, Elmostarchid B, Gazzaz M, Boucetta $M$ : Sudden onset of paraplegia caused by hemorrhagic spinal epidural angiolipoma. A case report. Eur Spine J 17(Suppl 2):S296-S298, 2008

2. Bailey D, Andrews J, Mazur E, Cleary J: Dorsal thoracic cord compression from a spinal angiolipoma. Case report and brief comment. Conn Med 64:267-269, 2000

3. Bender JL, Van Landingham JH, Manno NJ: Epidural lipoma producing spinal cord compression. J Neurosurg 41:100-103, 1974

4. Berenbruch K: Ein Fall von multiplen Angiolipomen kombiniert mit einem Angiom des Ruckenmark. Tubingen. Medical Faculty Universitat Tubingen, 1890

5. Dogan S, Arslan E, Sahin S, Aksoy K, Aker S: Lumbar spinal extradural angiolipomas. Two cases reports. Neurol Med Chir 46:157-160, 2006 
6. Fourney DR, Tong KA, Macaulay RJ, Griebel RW: Spinal angiolipoma. Can J Neurol Sci 28:82-88, 2001

7. Gelabert-GonzalezM, Agulleiro-Diaz J, Reyes-Santias RM: Spinal extradural angiolipoma with a literature review. Childs Nerv Syst 18:725-728, 2002

8. Gelabert-Gonzalez M, Garcia-Allut A: Spinal extradural angiolipoma: report of two cases and review of the literature. Eur Spine J 18:324-335, 2009

9. Hsu CH, Yang $\mathrm{CM}$, Cheng $\mathrm{CJ}$ : Angiolipoma detected by F-18 FDG positron emission tomography. Clin Nucl Med 28:604605, 2003

10. Hungs $M$, Pare LS: Spinal angiolipoma. Case report and literature review. J Spinal Cord Med 31:315-318, 2008

11. Kuroda $S$, Abe H, Akino M, Nagashima K: Infiltrating spinal angiolipoma causing myelopathy. Case report. Neurosurgery 27:315-318, 1990

12. Lin JJ, Lin F:Two entities in angiolipomas. A study of 459 cases of lipoma with review of literature on infiltrating angiolipoma. Cancer 34:720-727, 1974

13. Matsumoto $M$, Chiba K, Toyama $Y$, Takeshita K, Seichi A, Nakamura K, Arimizu J, Fujibayashi S, Hirabayashi S, Hirano T, Iwasaki M, Kaneoka K, Kawaguchi Y, Ijiri K, Maeda T, Matsuyama Y, Mikami Y, Murakami H, Nagashima H, Nagata K, Nakahara S, Nohara Y, Oka S, Sakamoto K, Takahashi M, Tanaka Y, Tani T, Tokuhashi Y, Uchida K, Yamamoto K, Yamazaki M, Yokoyama T, Yoshida M, Nishiwaki Y: Surgical results and related factors for ossification of posterior longitudinal ligament of the thoracic spine. A multi-institutional retrospective study. Spine 33:1034-1041, 2008

14. Miyamoto Y, Naka J, Asahi S, Mikami T, Sawada H, Sano K, Ichimaru K, Yamamoto K: Spinal extradural angiolipoma. A report of two cases and review of the literature. Kanto Seisaishi 40:420-424, 2009 (in Japanese)
15. Nagano S, ljiri $Y$, Yone $\mathrm{K}$, aketomi E, Nakahara S, Sako T: Extradural angiolipoma with thoracic myelopathy. A case report. Seikeigeka Saigaigeka 49:315-316, 2000 (in Japanese)

16. Okuyama K, Watanabe M, Matsumoto M, Maruiwa H, Chiba K, Fujimura S, Toyama Y: Spinal extradural angiolipoma. A report of five cases. Spine and Spinal Cord 11:196, 2000 (in Japanese)

17. Palkkovic S, Wassman $\mathrm{H}$, Bonse R, Kashab M: Angiolipoma of the spinal cord magnetic resonance imaging and microsurgical management. Surg Neurol 29:243-245, 1988

18. Poon TP, Behbahani M, Matoso IM, Katz MA, Pearl M: Epidural angiolipoma with spinal cord compression. J Natl Med Assoc 80:347-349, 1988

19. Preul MC, Leblanc R, Tampieri D, Robitaille Y, Pokrupa R: Spinal angiolipomas. Report of three cases. J Neurosurg 78:280-286, 1993

20. Provenzale JM, McLendon RE: Spinal angiolipomas. MR features. AJNR Am J Neuroradiol 17:713-719, 1996

21. Shuangshoti S, Hongsaprabhas C: Intraspinal epidural angiolipoma. J Med Assoc Thai 62:457-460, 1979

22. Stookey B: Intradural spinal angiolipoma. Report of a case and symptoms for 10 years in child aged 11 . Review of literature. Archieves of Neurology and Psychiatry 18:16-43, 1927

23. Takeuchi J, Handa H, Keyaki A, Haibara H, Ozaki S: Intracranial angiolipoma. Surg Neurol 15:110-113, 1981

24. Von Hanwehr R, Apuzzo MLJ, Ahmadi J, Chandrasoma P: Thoracic spinal angiolipoma. Case report and literature review. Neurosurgery 16:406-411, 1985

25. Wilkins PR, Hoddinott C, Hourihan MD: Intracranial angiolipoma. J Neurol Neurosurg Psychiatry 50:1057-1059, 1987 